\title{
Erratum to: Antibacterial activity of Eucalyptus globulus on cariogenic bacteria and its inhibitory effect on glucosyltransferase
}

\author{
Kenji Osawa $^{1}$ - Takahisa Saeki $^{1} \cdot$ Hideyuki Yasuda $^{1} \cdot$ Hiroshi Morita $^{2,3}$. \\ Koichi Takeya $^{2} \cdot$ Hideji Itokawa $^{2}$
}

Published online: 29 March 2015

(c) The Japanese Society of Pharmacognosy and Springer Japan 2015

\section{Erratum to: Natural Medicines (1998) 52(1):32-37}

In the original publication of the article, the legend of Fig. 3 was published incorrectly. The corrected version is given below:
Fig. 3 Relationship between surviving cells (S. mutans MT8148R) and exposure time to extracts A and B from $E$. globulus in BHI medium. Symbols: open circle control, filled circle $10 \mu \mathrm{g} / \mathrm{ml}$, open triangle $50 \mu \mathrm{g} / \mathrm{ml}$, filled triangle $100 \mu \mathrm{g} / \mathrm{ml}$, open square $200 \mu \mathrm{g} / \mathrm{ml}$

H. Itokawa: Passed away on 21 August 2013.

The online version of the original article can be found at http://ci.nii. ac.jp/naid/110008731817/en.

Kenji Osawa

oosawa_kenji@lotte.co.jp

1 Department of Basic Research, Lotte Co., Ltd, Central Laboratory, 3-1-1 Numakage, Mianmi-ku, Saitama 336-8601, Japan

2 Department of Natural Products and Medicinal Chemistry, School of Pharmacy, Tokyo University of Pharmacy and Life Science, 1432-1 Horinouchi, Hachioji, Tokyo 192-0392, Japan

3 Present Address: Department of Pharmacognosy, School of Pharmacy, Hoshi University, 2-4-41 Ebara, Shinagawa, Tokyo 142-8501, Japan 